\title{
RANCANG BANGUN PENGAMAN MESIN ATM MENGGUNAKAN RFID BERBASIS MIKROKONTROLER ATMega8535
}

\author{
Freddy Artadima Silaban*1 ${ }^{1}$, Lussiana ETP ${ }^{2}$ \\ ${ }^{1}$ Program Studi Teknik Elektro Fakultas Teknik Universitas Mercu Buana \\ ${ }^{2}$ Program Studi Sistem Komputer Fakultas Ilmu Komputer dan Teknologi Informasi Universitas \\ Gunadarma \\ Email: ${ }^{* 1}$ freddy.artadima@mercubuana.ac.id, ${ }^{2}$ ussie@ @staff.gunadarma.ac.id
}

\begin{abstract}
Abstrak
Brankas uang merupakan salah satu tempat yang dapat digunakan untuk menyimpan uang sehingga lebih aman dari tangan-tangan yang tidak berhak. Mesin ATM hanya memiliki sistem security hanya sebatas sensor. Hal ini kurang efesien dalam keamanan mesin ATM. Tujuan penelitian ini adalah merancang dan membuat sistem keamanan mesin ATM berbasis mikrokontroler yang dikombinasikan dengan beberapa sensor keamanan dengan tujuan mendapatkan keamanan yang lebih optimal dan mengimplementasikan RFID sebagai pendukung keamanan ATM. Metode yang digunakan pada penelitian ini menggunakan RFID Reader sebagai media input, website sebagai media informasi secara online sekaligus pengendali, dan mikrokontroler ATMega8535 sebagai pusat pemrosesan. Dari hasil perancangan dan pengujian yang sudah dilakukan menunjukkan bahwa alat bekerja sesuai dengan program yang sudah ditanamkan pada mikrokontroler ATMega 8535 dan rancangan alat ini dapat dikendalikan melalui website, serta setiap kondisi mesin ATM baik yang membuka menggunakan ID tag dan membongkar mesin ATM ditampilkan di LCD dan website.
\end{abstract}

Kata Kunci-RFID, Sensor Infrared-Fotodioda, Website, Mikrokontroler ATMega 8535.

\begin{abstract}
Safe money is one place that can be used to save money so that it is safer from unauthorized hands. ATM machines only have a security system limited to sensors. This is less efficient in the security of ATM machines. The purpose of this study is to design and create an ATM machine based on microcontroller security systems combined with several security sensors with the aim of obtaining more optimal security and implementing RFID as an ATM security support. The method used in this study uses RFID Reader as an input media, a website as an online information media as well as a controller, and an ATMega8535 microcontroller as a processing center. From the results of the design and testing that have been done shows that the tool works in accordance with the program that has been implanted in the ATMega 8535 microcontroller and the design of this tool can be controlled through the website, as well as any ATM machine conditions that open using ID tags and dismantle ATM machines displayed on the LCD and the website.
\end{abstract}

Keywords-RFID, Infrared-Photodiode Sensor, Website, Microcontroller ATMega 8535.

\section{PENDAHULUAN}

Brankas uang merupakan salah satu tempat yang dapat digunakan untuk 
menyimpan uang sehingga lebih aman dari tangan-tangan yang tidak berhak. Anjungan Tunai Mandiri (ATM) memiliki security terdiri dari Safe Door Lock (sensor bila kunci terbuka), Alarm Sensor, Seismic Detector, Jiiter (menggetarkan kartu ketika masuk ke mesin ATM), Blue Ink (apabila brankas dibongkar otomatis uang yang didalam ATM tercampur tinta), Cash Handler (sensor bila ada uang tersangkut di mesin), Temperatur Mesin, dan Resi Print Sensor[1]. Pengamanan menggunakan sebatas sensor tergolong lemah, karena ketika sensor mendeteksi tidak menginformasikan secara langsung ke pihak keamanan bank. Hal ini tentunya kurang efisien dalam menjalankan suatu sistem keamanan disuatu mesin ATM. Sementara saat ini telah dikenal adanya teknologi RFID (Radio Frequency Identification) yang banyak digunakan perusahaan bidang komersil sebagai identifikasi misalnya untuk pelacakan bagasi di bandara, pelacakan identitas untuk memverifikasi keaslian barang, mesin pembaca dokumen berjalan, melacak hewan dengan memasukan label RFID [2]. RFID (Radio Frequency Identification) merupakan suatu metode identifikasi dengan menggunakan sarana yang disebut label RFID atau transfonder untuk menyimpan dan mengambil data dari jarak jauh. Berdasarkan uraian diatas, penelitian ini memberikan solusi alternatif untuk pengaman mesin ATM menggunakan RFID (Radio Frequency Identification)[3]. Tujuan dari perancangan ini adalah untuk membangun keamanan mesin ATM berbasis mikrokontroler ATMega 8535 dengan RFID untuk sebagai akses membuka pintu mesin ATM.

\section{METODE PENELITIAN}

Proses tahap penyelesaian, penelitian ini terdiri dari tahap penelitian dan pendukung komponen peralatan lainnya. Tahap penelitian terdiri atas gambaran umum alat, tahap analisis blok diagram, tahap analisis input dan output, tahap analisis flowchart, dan tahap analisis software. Rancang bangun pengaman mesin ATM berbasis mikrokontroler atmega 8535 adalah sebuah rancangan alat yang digunakan untuk memantau setiap pekerja yang membuka mesin ATM. Selain itu alat ini dikontrol jarak jauh menggunakan sebuah interface yaitu website. Dengan rancangan alat ini, setiap kondisi dari mesin ATM akan tampil diwebsite dan LCD. Apabila terjadi pembongkaran paksa mesin ATM maka petugas dapat bertindak cepat memberi pengamanan.

\section{Rancangan Blok Diagram}

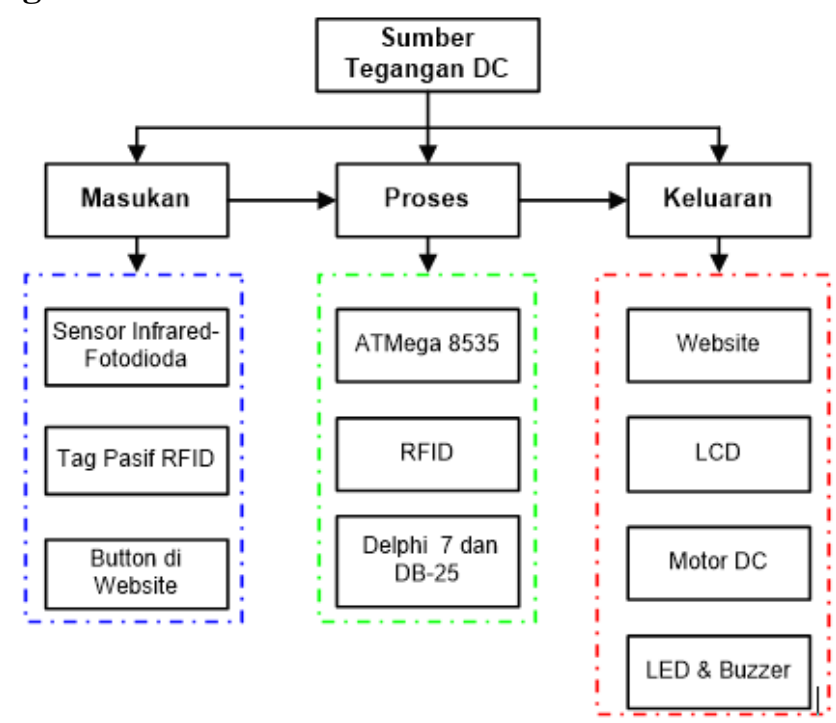

Gambar 1. Rancangan Blok Diagram 
Pada gambar 1 rancangan umumsistem yang terdiri dari atas sumbertegangan, rancangan blok masukan. Rancangan blok sumber tegangan dc merupakan media penyuplai seluruh tegangan ke blok masukan, blok proses, dan blok keluaran supaya rangkaian dapat bekerja sesuai dengan yang diharapkan. Sumber tegangan dc diperoleh dari adaptor. Tegangan +9 volt dari adaptor dihubungkan dengan ic regulator 7805 yang berfungsi untuk mengaktifkan sistem minimun tegangan pada mikrokontroler atmega 8535. Output tegangan dari mikrokontroler sebesar +5 volt.

\section{Rancangan Blok Masukan}

Rancanganblok masukan berfungsi untuk mendata setiap komponen yang digunakan sebagai media masukan yang di proses sehingga menghasilkan output sesuai yang diharapkan.

\section{Sensor Infrared-Fotodioda}

Sensor infrared dan fotodioda memiliki fungsi yang saling terkait, dimana infrared sebagai transmitter (pemancar) dan fotodioda sebagai receiver (penerima) cahaya dari infrared, seperti gambar 2 berikut .

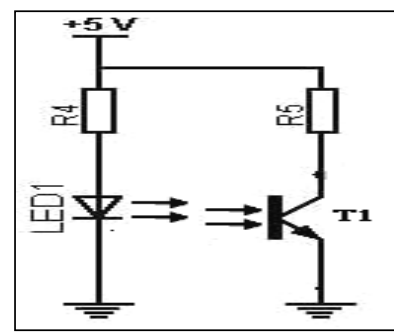

Gambar 2. Sensor Infrared Fotodioda

Sensor infrared-fotodioda pada rangkaian rancangan alat ini memiliki prinsip kerja yaitu jika cahaya yang dikirimkan oleh infrared terhalang oleh manusia dan benda lainnya, maka logika yang diterima pemroses logika 0. Jika cahaya yang dikirimkan oleh infrared diterima oleh fotodioda atau dibuat sejajar, maka logika yang diterima oleh pemroses logika 1.

\section{Tag Pasif RFID}

Tag pasif RFID adalah tag yang tidak memiliki power supply seperti baterai, sehingga membutuhkan pembaca responden. Tag RFID pasif memiliki kode ASCII yang berbeda-beda dan unik. Tag pasif RFID seperti gambar 3 berikut.

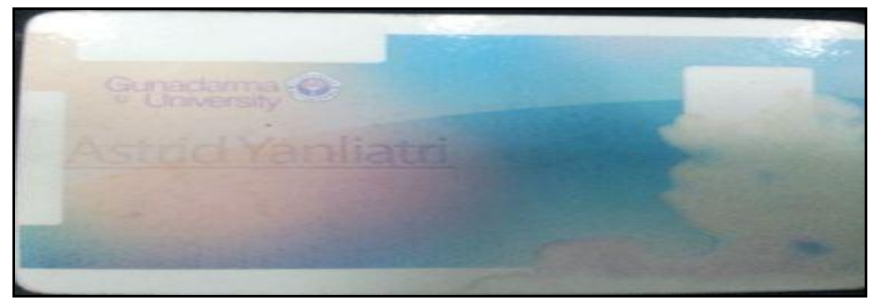

Gambar 3. Tag RFID Pasif

RFID tag pasif berbeda dengan RFID tag aktif dimana RFID tag pasif memiliki kapasitas yang lebih besar, sedangkan tag aktif terdiri dari antena dan chip. RFID tag pasif memiliki kerja apabila rfid tag pasif didekatkan dengan rfid reader (ID-12), maka rfid id-12 membaca data kode ASCII pada tag pasif.

\section{Button Pada Website}

Button pada website dirancang menggunakan perangkat lunak dreamweaver yang berekstension php. Button pada website terdiri dari 2 (dua) yaitu Open The Door Mechine ATM dan Close The Door Mechine ATM, ditunjukkan seperti gambar 4 berikut. 


\section{Open The Door Mechine ATM Close The Door Mechine ATM}

Gambar 4. Button Input pada Website

Button yang pertama Open The Door Mechine ATM berfungsi untuk button membuka pintu mesin ATM secara manual. Button kedua Close The Door Mechine ATM berfungsi untuk menutup pintu mesin ATM secara manual. Kedua button pada gambar 4 digunakan secara online.

\section{Rancangan Blok Proses}

Rancangan blok proses merupakan kondisi masukan yang telah diperoleh dari input, selanjutnya diteruskan untuk diproses agar menghasilkan keluaran. Dalam racangan alat ini blok proses terdiri dari ATMega 8535, RFID ID-12 (Reader), Delphi 7, dan DB-25.

\section{Mikrokontroler ATMega 8535}

Mikrokontroler atmega 8535 pada rancangan rangkaian ini digunakan untuk memproses data yang diterima dari media input seperti RFID reader dan sensor infrared-fotodioda. Pada mikrokontroler pin output dari rfid reader dihubungan dengan PinD.0(receiver). Cara kerja rfid reader yaitu membaca data yang ada pada tag rfid pasif dalam bentuk kode ASCII.

$$
\text { PDIP }
$$

\begin{tabular}{|c|c|c|c|c|}
\hline (ХСК/TO) РВO С & 1 & 40 & 口 PAO & $(A D C O)$ \\
\hline (T1) PB1 & 2 & 39 & P PA1 & (ADC1) \\
\hline (INT2/AINO) PB2 & 3 & 38 & D PA2 & (ADC2) \\
\hline (OCO/AIN1) PB3 & 4 & 37 & P РА3 & (ADC3) \\
\hline (डS) PB4 & 5 & 36 & 巨 PA4 & (ADC4) \\
\hline (MOSI) PB5 & 6 & 35 & E PA5 & (ADC5) \\
\hline (MISO) PB6 & 7 & 34 & 巨 PA6 & (ADC6) \\
\hline (SCK) PB7 G & 8 & 33 & 巨 PA7 & (ADC7) \\
\hline RESET & 9 & 32 & AREF & \\
\hline vcc & 10 & 31 & GND & \\
\hline GND & 11 & 30 & AVCC & \\
\hline XTAL2 & 12 & 29 & 口 PC7 & (TOsc2) \\
\hline XTAL1 & 13 & 28 & 巨 PC6 & (TOSC1) \\
\hline (RXD) PDO & 14 & 27 & PC5 & \\
\hline (TXD) PD1 G & 15 & 26 & PC4 & \\
\hline (INTO) PD2 & 16 & 25 & PC3 & \\
\hline (INT1) PD3 & 17 & 24 & PC2 & \\
\hline (OC1B) PD4 & 18 & 23 & 巨 $\mathrm{PC} 1$ & (SDA) \\
\hline (OC1A) PD5 & 19 & 22 & PCO & $(\mathrm{SCL})$ \\
\hline (ICP1) PD6 C & 20 & 21 & PD7 & (OC2) \\
\hline
\end{tabular}

Gambar 5. Mikrokontroler ATMega 8535

Sensor infrared-fotodioda dihubungkan pada Port A.0, apabila sinar dari infrared tidak diterima oleh fotodioda atau terhalang, maka logika di Port A.0 logika 0 dengan tegangan 0 volt. Jika sinar dari infrared diterima oleh fotodioda maka logika di PA.0 logika 1 dengan tegangan 4.5 volt.Keluaran pada PORTD yaitu PORTD.5, PORTD.6 dan PORTD.7 dikirimkan ke port paralel DB25 melalui pin status register yaitu pin 11, 12 dan 13. Dari pin-pin tersebut data diproses oleh software Delphi 7 yang hasil pemrosesannya kemudian dikirimkan ke web.

Port Paralel DB 25

DB-25 merupakan port paralel berfungsi untuk menghubungkan satu device dengan device yang lain. DB 25 dapat mengirimkan data 8 bit dalam setiap waktu. 


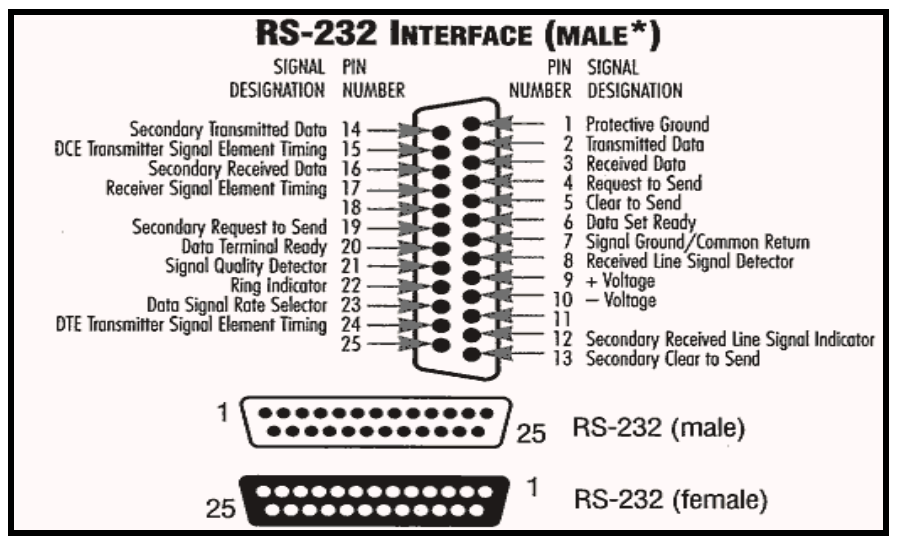

Gambar 6. Port Paralel DB25

Fungsi DB 25 pada rancangan alat ini adalah untuk proses, apabila salah satu button di klik pada website, maka web akan mengirimkan data file berekstension txt yang diproses oleh Delphi 7 dengan cara membandingkan data yang masuk dengan data yang telah dibuat sebelumnya, selanjutnya hasil keluaran akan dikirimkan melalui port dat bus (D0 dan D2).

\section{Perangkat Lunak Delphi 7}

Perangkat lunak Delphi 7 merupakan program turunan dari turbo pascal berbasis GUI. Delphi 7 pada rancangan rangkaian alat ini berfungsi untuk menghubungkan alat dan website dengan interface port paralel db 25. Jika suatu kondisi ditampilkan pada website, maka data tersebut dikirimkan terlebih dahulu melalui port paralel $\mathrm{db} 25$, program delphi melanjutkan informasi tersebut ke website.

\section{Rancangan Blok Keluaran}

Blok keluaran merupakan hasil yang diperoleh dari proses. Pada rancangan alat ini keluaran terdiri dari website, motor dc, LCD 2x16, LED, dan buzzer.

\section{Rancangan Website}

Website adalah merupakan sumber daya internet untuk memperoleh informasi dan bahkan melakukan transaksi. Website dalam rancangan alat ini di desain menggunakan program dreamweaver 8 .

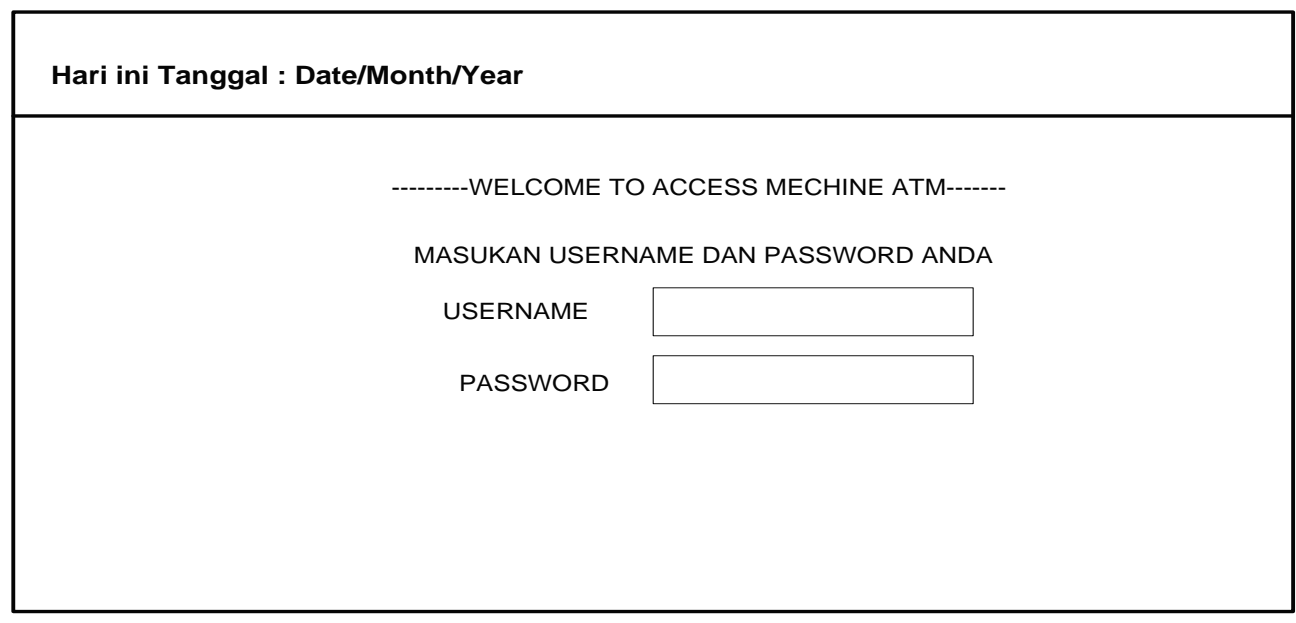

Gambar 7. Rancangan Antarmuka Website

Antarmuka website merupakan awal pertama ketika akses domain website maka tampil perintah untuk memasukan username dan password.Fungsi memasukan username dan password yaitu supaya setiap orang yang ingin mengakses domain website ini tidak sembarangan.

Motor DC

Motor DC merupakan media output yang menggerakkan pintu mesin ATM untuk membuka dan menutup pintu. 


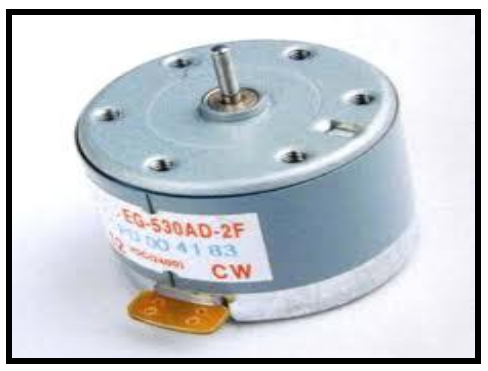

Gambar 8. Motor DC

Motor DC dihubungkan dengan ic motor driver dari motor driver menerima input dari port paralel DB 25 terhubung ke pin data DB 25. Port DB 25 menghubungkan antara alat dan komputer dengan program Delphi 7 sebagai user interface. Motor bergerak membuka dan menutup ketika button pada website dipilih .

$L C D$

Liquid Crystal Display (LCD) pada rancangan alat ini merupakan media output yang digunakan untuk menampilkan informasi kondisi mesin ATM. LCD diletakkan dirancangan alat, dengan tujuan untuk memberikan informasi ke user seperti "AKSES MESIN ATM INPUT U'R TAG", setelah ditempel di lcd muncul informasi "ACCESS ACCEPT" bertujuan supaya user menunggu hasil verifikasi dari administrator web untuk membuka pintu, jika kartu atau tag yang ditempelkan benar maka administrator memberikan hak akses membuka mesin ATM.

\section{Rancangan Rangkaian Secara Detail}

Sebelum melakukan uji coba menggunakan perangkat keras, tahap perancangan analisis rangkain diperlukan untuk mengetahui alur kerja alat seperti pada gambar 9 dibawah.

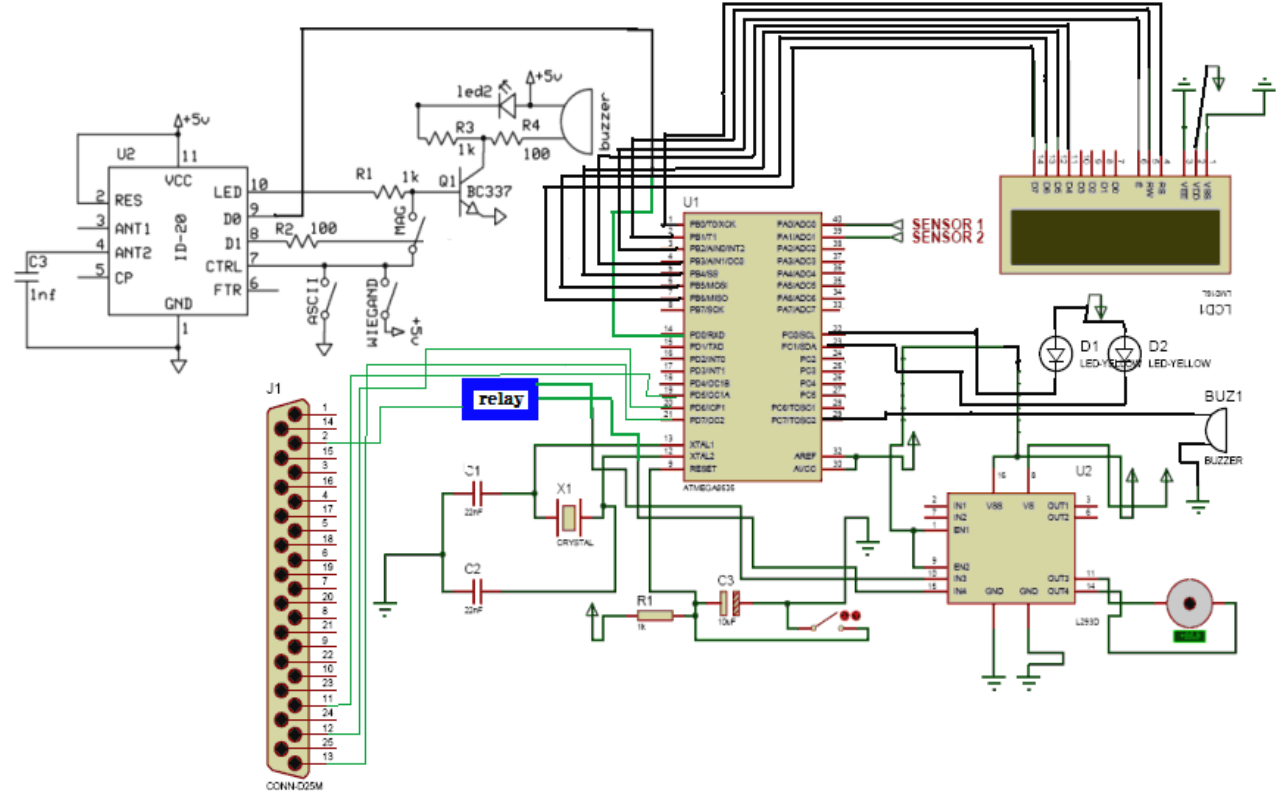

Gambar 9. Rancangan Alat Secara Detail

Output pada rancangan alat ini berupa informasi pada LCD untuk blok monitoring, output informasi di website untuk blok pengendali dan monitoring, dan pergerakan motor dc arah CW (Clock Wise) dan CCW (Counter Clock Wise). Saat sensor 1 dan sensor 2 tidak terhalang oleh benda apapun maka muncul di LCD dan website "AKSES MESIN ATM INPUT U'R TAG". Jika sensor 1 dan sensor 2 terhalang maka muncul informasi di LCD dan Website "MESIN ATM BAHAYA".

Motor DC akan bergerak secara manual, ketika administrator pilih menekan button di website "OPEN THE DOOR MESIN ATM". Pintu mesin ATM dibuka apabila kode ASCII 
yang ditempelkan ke RFID reader sesuai dengan kode ASCII yang sudah ditanamkan kedalam mikrokontroler. Jika kode ASCII dalam kartu yang ditempelkan berbeda dengan program yang sudah ditanamkan, maka muncul di LCD dan website "ACCESS DENIED". Button pada website terdiri dari dua yaitu button "OPEN THE DOOR MECHINE ATM" yang berfungsi untuk membuka pintu mesin ATM secara manual. Button "CLOSE THE DOOR MECHINE ATM" yang berfungsi untuk menutup mesin ATM secara manual.

\section{Alur Program Rancangan Alat}

Alur Cara Kerja Sensor

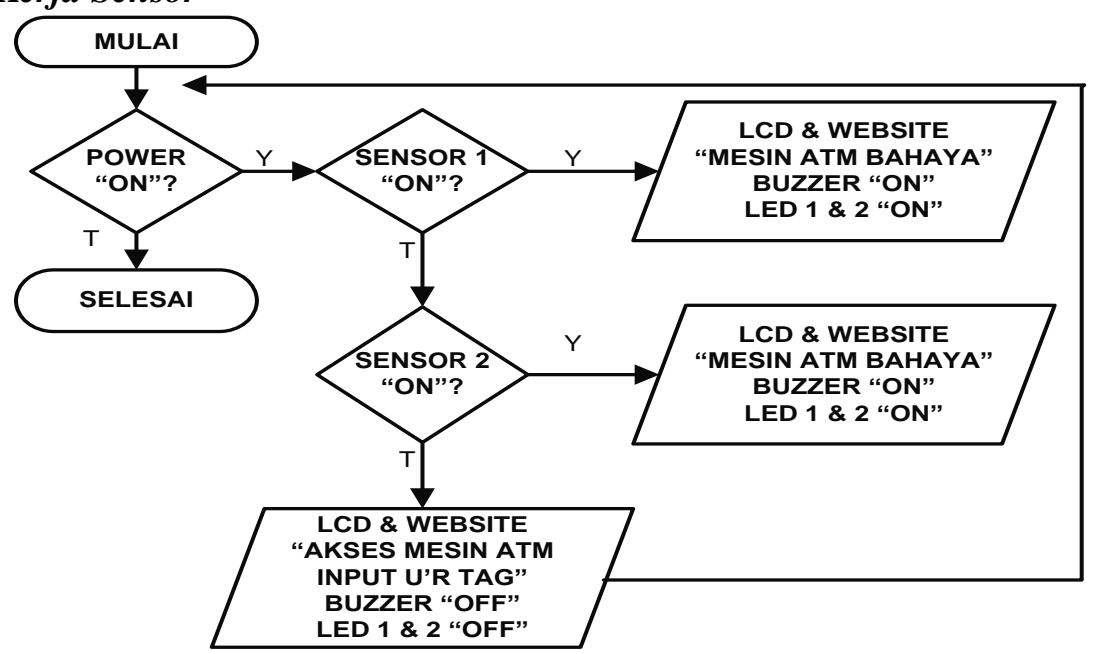

Gambar 10. Alur Kerja Sensor

Alat yang sudah mendapatkan tegangan (power) jika "YA" masuk ke kondisi selanjutnya, apakah sensor 1 "ON"?. Jika "YA" maka tampil di LCD dan Website "MESIN ATM BAHAYA", Buzzer "on", dan Led 1 \& 2 "on". Jika sensor 1 off maka lanjut ke kondisi selanjutnya, apakah sensor 2 "ON". Jika "YA" maka tampil di LCD dan Website "MESIN ATM BAHAYA" Buzzer "on", dan Led 1 \& 2 "on". Jika sensor 2 off maka tampil di LCD dan Website "AKSES MESIN ATM INPUT U'R TAG", Buzzer "off", dan Led 1 \& 2 "off".

\section{Cara Kerja RFID Reader dan Tag Pasif RFID}

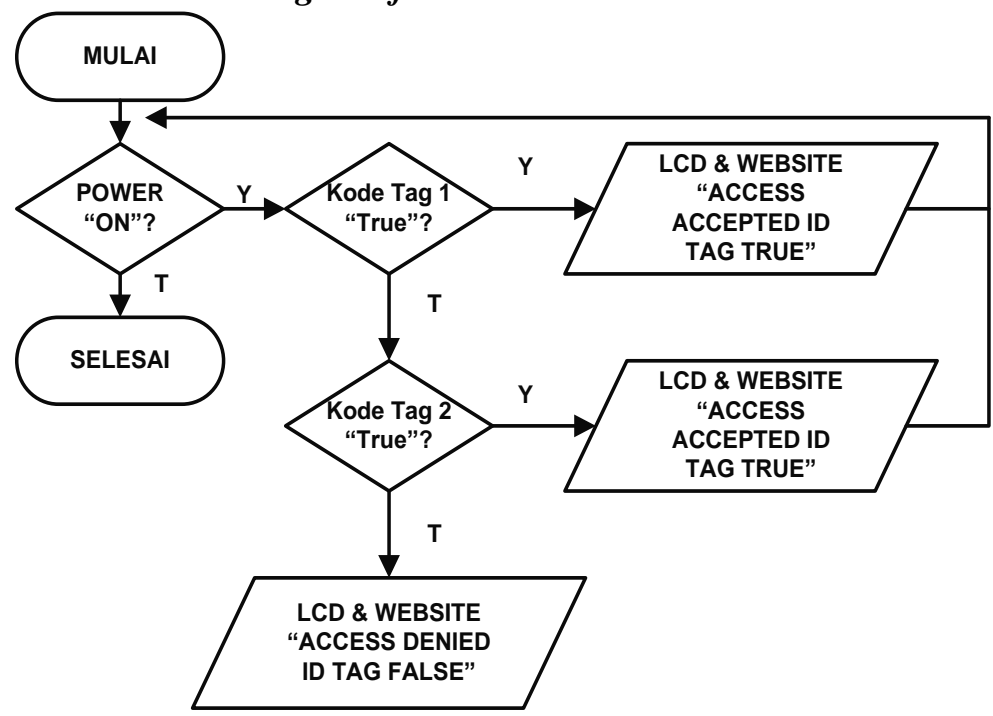

Gambar 11. Alur Kerja RFID Reader dan Tag Pasif RFID 
Apabila kondisi Power "ON" maka lanjut ke kondisi selanjutnya. Apabila kode tag 1 ditempelkan pada RFID reader benar maka muncul di LCD dan Website "ACCESS ACCEPTED ID TAG TRUE", maka administrator membuka pintu mesin ATM dengan memilih button "OPEN THE DOOR MECHINE ATM" di website. Jika kode tag 1 ditempelkan pada RFID Reader salah maka muncul informasi di LCD dan Website "ACCESS DENIED ID TAG FALSE". Apabila kode tag 2 ditempelkan pada RFID reader benar maka muncul di LCD dan Website "ACCESS ACCEPTED ID TAG TRUE", maka administrator membuka pintu mesin ATM dengan memilih button "OPEN THE DOOR MECHINE ATM" di website. Jika kode tag 2 ditempelkan pada RFID Reader salah maka muncul informasi di LCD dan Website "ACCESS DENIED ID TAG FA.

\section{Alur Kerja Pengendali Website}

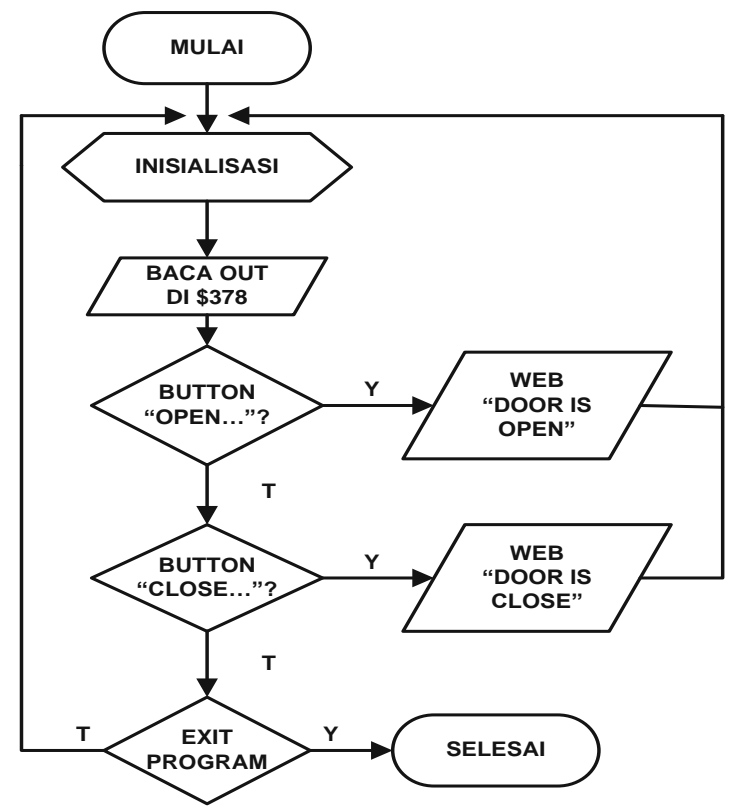

Gambar 12. Alur Kerja Pengendali Website

Dimana output pada gambar 12 merupakan pembacaan port paralel DB25 dalam pemrograman delphi 7. Jika pada web dipilih button "OPEN THE DOOR MECHINE ATM" maka tampil di website "DOOR IS OPEN". Jika pada web dipilih "CLOSE THE DOOR MECHINE ATM" maka akan tampil di website "DOOR IS CLOSE". Jika keluar dari program maka program yang sedang dijalankan selesai, jika tidak maka program ini selalu berulang selama program tetap berjalan.

\section{HASIL DAN PEMBAHASAN}

\section{Hasil Uji Sensor Infrered-Fotodioda}

Hasil pengukuran sensor Infrared dan fotodioda yang dirancang berdasarkan langkahlangkah perancangan yang sudah dilakukan.

Tabel 1. Hasil Uji Coba Sensor Infrared-Fotodioda

\begin{tabular}{|c|c|c|c|c|c|c|c|}
\hline \multirow{2}{*}{$\begin{array}{l}\text { Tegangan } \\
\text { DC } 9 \text { Volt }\end{array}$} & \multirow{2}{*}{ PORTA } & \multicolumn{2}{|c|}{ Sensor } & \multicolumn{3}{|c|}{ Keluaran } & \multirow{2}{*}{ Keterangan } \\
\hline & & 1 & 2 & LCD16x2 & Website & Buzzer & \\
\hline \multirow{2}{*}{ Ya } & $0 x F E$ & On & Off & $\begin{array}{ll}\text { Mesin } & \text { ATM } \\
\text { Bahaya } & \end{array}$ & $\begin{array}{ll}\text { Mesin } & \text { ATM } \\
\text { Bahaya } & \end{array}$ & On & Sesuai \\
\hline & 0xFD & Off & On & $\begin{array}{ll}\text { Mesin } & \text { ATM } \\
\text { Bahaya } & \end{array}$ & $\begin{array}{ll}\text { Mesin } & \text { ATM } \\
\text { Bahaya } & \end{array}$ & On & Sesuai \\
\hline
\end{tabular}




\begin{tabular}{|c|c|c|c|c|c|c|c|}
\hline & OxFF & Off & Off & $\begin{array}{l}\text { Akses Mesin } \\
\text { ATM Input } \\
\text { U'R TAG }\end{array}$ & $\begin{array}{l}\text { Akses Mesin } \\
\text { ATM Input U'R } \\
\text { TAG }\end{array}$ & Off & Sesuai \\
\hline Tidak & Off & Off & Off & - & - & Off & Tidak Sesuai \\
\hline
\end{tabular}

Pada tabel 1 merupakan hasil pengujian alur kerja infrared-fotodioda, dari hasil pengujian diperoleh jika sumber tegangan DC mengalir pada rangkaian maka alat akan berkerja secara terus menerus. Jika sensor 1 dan sensor 2 "On" maka tampil informasi di LCD 16x2 dan Website "Mesin ATM Bahaya" dan Buzzer "On".

\section{Hasil Uji Coba RFID Reader dan Tag Pasif RFID}

Berikut hasil pengukuran pada RFID Reader dan Tag Pasif RFID dimana hasil kondisi yang dirancang berdasarkan langkah-langkah perancangan yang sudah dilakukandari hasil pengujian diperoleh, jika rangkaian RFID dialiri tegangan 9 Volt maka RFID reader aktif. Berikutnya jika ID tag yang dimasukkan benar maka tampil di LCD dan Website "Access Accepted ID TAG True". Apabila ID tag yang dimasukkan salah, maka tampil di LCD dan Website "Access Denied ID Tag False". Jika tidak di aliri tegangan maka RFID reader dan komponen yang lainnya tidak bisa bekerja sesuai dengan yang diharapkan seperti pada tabel 2 berikut.

Tabel 2. Hasil Uji Coba Pada RFID Reader dan Tag Pasif RFID

\begin{tabular}{|c|c|c|c|c|c|c|}
\hline \multirow{2}{*}{$\begin{array}{c}\text { Tegangan } \\
\text { DC } \\
9 \text { Volt } \\
\end{array}$} & \multirow[t]{2}{*}{ PORTD } & \multicolumn{2}{|c|}{$\begin{array}{l}\text { ID Tag Pasif } \\
\text { RFID }\end{array}$} & \multicolumn{2}{|c|}{ Keluaran } & \multirow[t]{2}{*}{ Keterangan } \\
\hline & & Benar & Salah & LCD16x2 & Website & \\
\hline \multirow{3}{*}{ Ya } & $0 x E F$ & Ya & - & $\begin{array}{l}\text { Access } \\
\text { Accepted ID } \\
\text { TAG True }\end{array}$ & $\begin{array}{l}\text { Access } \\
\text { Accepted ID } \\
\text { TAG True }\end{array}$ & Sesuai \\
\hline & $0 x B F$ & - & YA & $\begin{array}{l}\text { Access } \\
\text { Denied ID } \\
\text { TAG False }\end{array}$ & $\begin{array}{l}\text { Access } \\
\text { Denied ID } \\
\text { TAG False }\end{array}$ & Sesuai \\
\hline & $0 x F F$ & - & - & $\begin{array}{l}\text { Akses Mesin } \\
\text { ATM Input } \\
\text { U'R TAG }\end{array}$ & $\begin{array}{lr}\text { Akses } & \text { Mesin } \\
\text { ATM Input } \\
\text { U'R TAG }\end{array}$ & Sesuai \\
\hline Tidak & Off & Off & Off & - & - & Tidak Sesuai \\
\hline
\end{tabular}

\section{Hasil Uji Coba Pengendali Pada Website}

Berikut hasil pengukuran pada kondisi pengendali website yang dirancang berdasarkan langkah-langkah perancangan yang sudah dilakukan

Tabel 3. Hasil Uji Coba Pada Website

\begin{tabular}{|c|c|c|c|}
\hline NO & \multicolumn{3}{|l|}{ KONDISI } \\
\hline \multirow{3}{*}{1} & \multirow{3}{*}{$\begin{array}{l}\text { Terhubung } \\
\text { Akses } \\
\text { Internet }\end{array}$} & \multicolumn{2}{|c|}{ LAN (Local Area Network) } \\
\hline & & YA & TIDAK \\
\hline & & 100.0 Mbps & $2<\mathrm{Mbps}$ \\
\hline \multirow{3}{*}{2} & \multirow{3}{*}{$\begin{array}{l}\text { Terhubung } \\
\text { Akses } \\
\text { Internet }\end{array}$} & \multicolumn{2}{|l|}{ Modem } \\
\hline & & YA & TIDAK \\
\hline & & 10.0 Mbps & $2<\mathrm{Mbps}$ \\
\hline \multirow{4}{*}{3} & \multirow{4}{*}{$\begin{array}{l}\text { Memilih } \\
\text { Button } \\
\text { Pada Web }\end{array}$} & Button & \\
\hline & & $\begin{array}{l}\text { Open The Door } \\
\text { Mechine ATM }\end{array}$ & $\begin{array}{l}\text { Open The Door Mechine } \\
\text { ATM }\end{array}$ \\
\hline & & Keluaran & \\
\hline & & Motor DC & Motor DC \\
\hline
\end{tabular}




\section{\begin{tabular}{|l|l|l|l|}
\hline & & Bergerak Arah CW & Bergerak Arah CCW \\
\hline
\end{tabular}}

Pada tabel 3 merupakan hasil pengujian alur kerja pengendali pada website,jika terhubung dengan internet dengan kecepatan antara 10.0 Mbps sampai 100 Mbps pengendalian alat dapat dilakukan dari website. Jika tidak terhubung dengan internet atau terhubung ke internet dengan kecepatan lebih kecil dari $2 \mathrm{Mbps}$ pengendalian alat tidak dapat bekerja dengan dengan optimal.

\section{Hasil Uji Coba Alat Secara Keseluruhan}

Setelah dilakukan uji coba secara per blok diperoleh hasil uji coba secara keseluruhan seperti pada tabel 4 .

Tabel 4. Hasil Uji Coba Secara Keseluruhan

\begin{tabular}{|c|c|c|c|c|c|c|c|c|c|c|c|}
\hline \multirow[b]{2}{*}{$\begin{array}{l}\mathrm{N} \\
0\end{array}$} & \multicolumn{2}{|c|}{ Blok Masukan } & \multicolumn{3}{|c|}{ Terima Data } & \multirow[b]{2}{*}{ Kondisi. } & \multirow[b]{2}{*}{$\operatorname{LCD} 16 x 2$} & \multirow[b]{2}{*}{ Website } & \multirow[b]{2}{*}{ Buzzer } & \multirow[b]{2}{*}{$\begin{array}{l}\text { LED } \\
1 \text { dan } \\
\text { LED } \\
2\end{array}$} & \multirow[b]{2}{*}{ Ket } \\
\hline & $\begin{array}{c}\text { ID } \\
\text { Tag } \\
\text { Pasif }\end{array}$ & $\begin{array}{l}\text { Sensor } \\
1 \text { dan } \\
\text { sensor } \\
2\end{array}$ & $\begin{array}{l}\text { Port } \\
\text { D.0 }\end{array}$ & $\begin{array}{l}\text { Port } \\
\text { A.0 }\end{array}$ & $\begin{array}{l}\text { Port } \\
\text { A.1 }\end{array}$ & & & & & & \\
\hline 1 & Benar & - & Ia & Tidak & Tidak & $\begin{array}{l}\text { Mesin } \\
\text { ATM }\end{array}$ & $\begin{array}{l}\text { Access } \\
\text { Accepted } \\
\text { ID Tag } \\
\text { True }\end{array}$ & $\begin{array}{l}\text { Access } \\
\text { Accepted } \\
\text { ID Tag } \\
\text { True }\end{array}$ & OFF & ON & $\begin{array}{l}\text { Sesu } \\
\text {-ai }\end{array}$ \\
\hline 2 & Salah & - & Ya & Tidak & Tidak & $\begin{array}{l}\text { Mesin } \\
\text { ATM }\end{array}$ & $\begin{array}{l}\text { Access } \\
\text { Denied ID } \\
\text { Tag False }\end{array}$ & $\begin{array}{l}\text { Access } \\
\text { Denied } \\
\text { ID Tag } \\
\text { False }\end{array}$ & OFF & ON & $\begin{array}{l}\text { Sesu } \\
\text {-ai }\end{array}$ \\
\hline 3 & - & ON & Tidal & Ya & Tidak & $\begin{array}{l}\text { Mesin } \\
\text { ATM }\end{array}$ & $\begin{array}{l}\text { Desin } \\
\text { ATM } \\
\text { Bahaya }\end{array}$ & $\begin{array}{l}\text { Desin } \\
\text { ATM } \\
\text { Bahaya }\end{array}$ & ON & ON & $\begin{array}{l}\text { Sesu } \\
\text {-ai }\end{array}$ \\
\hline 4 & - & ON & Tidak & Tidak & Ia & $\begin{array}{l}\text { Mesin } \\
\text { ATM }\end{array}$ & $\begin{array}{l}\text { Dresin } \\
\text { ATM } \\
\text { Bahaya }\end{array}$ & $\begin{array}{l}\text { Desin } \\
\text { ATM } \\
\text { Bahaxa }\end{array}$ & ON & ON & $\begin{array}{l}\text { Sesut } \\
\text {-ai }\end{array}$ \\
\hline 5 & - & ON & Tidak & Ia & Ya & $\begin{array}{l}\text { Mesin } \\
\text { ATM }\end{array}$ & $\begin{array}{l}\text { Desin } \\
\text { ATM } \\
\text { Bahaya }\end{array}$ & $\begin{array}{l}\text { Desin } \\
\text { ATM } \\
\text { Bahaxa }\end{array}$ & ON & ON & $\begin{array}{l}\text { Sesul } \\
\text {-ai }\end{array}$ \\
\hline 6 & - & OFF & Tidak & Tidak & Tidak & $\begin{array}{l}\text { Mesin } \\
\text { ATM }\end{array}$ & $\begin{array}{l}\text { Akses } \\
\text { Mesin } \\
\text { ATM } \\
\text { Input U'R } \\
\text { Tag }\end{array}$ & $\begin{array}{l}\text { Akses } \\
\text { Mesin } \\
\text { ATM } \\
\text { Input } \\
\text { U'R Tag }\end{array}$ & OFF & OFF & $\begin{array}{l}\text { Sesu } \\
\text {-ai }\end{array}$ \\
\hline
\end{tabular}

Tabel 4 merupakan hasil uji coba secara keseluruhan setelah dilakukan pengujian dan pengambilan data dari rancangan alat yang sudah dibuat. Untuk hasil pengujian secara keseluruhan ini sesuai dengan program yang sudah ditanamkan pada Mikrokontroler ATMega 8535 dan rangkaian yang sudah dikombinasikan.

\section{HASIL IMPLEMENTASI ALAT}

Setelah secara keseluruhan selesai dilakukan pengujian terhadap tiap-tiap perancangan yang ada pada penelitian ini, langkah selanjutnya mengimplementasikan penelitian. 


\section{Uji Coba Tag ID Benar}

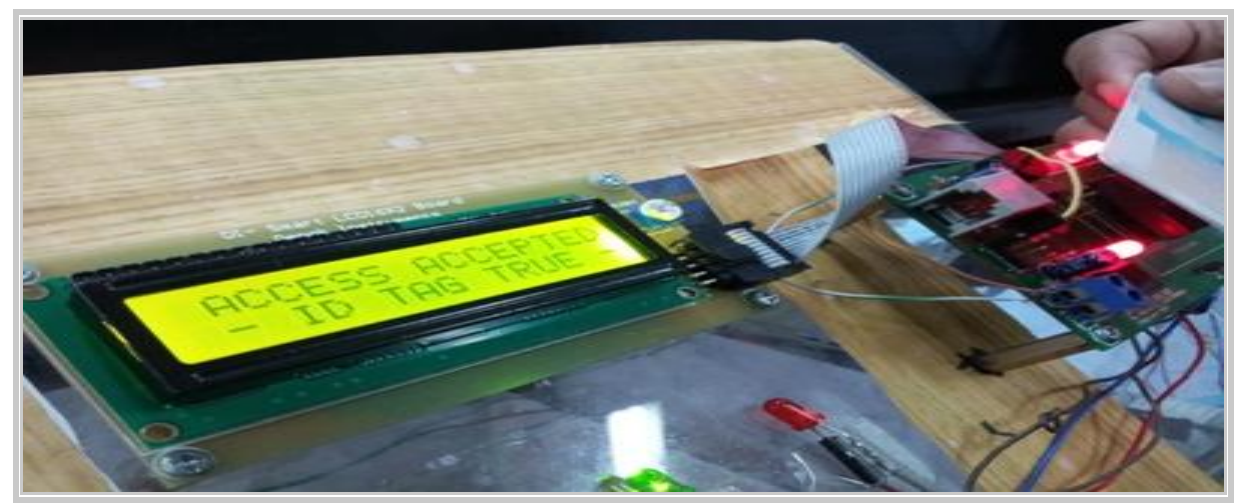

Gambar 13. Uji Coba TAG ID Benar

Gambar 13 merupakan hasil uji coba dengan memasukan kode ID tag yang benar, tampil di lcd kalimat "ACCESS ACCEPTED" dan "ID TAG TRUE". Selanjutnya tampil diwebsite seperti gambar 14 berikut.

\section{STATUS $N$}

\section{ACCESS ACCEPTED}

ID TAG TRUE

\section{Gambar 14. Access Accepted "ID TAG True"}

\section{Uji Coba Tag ID Salah}

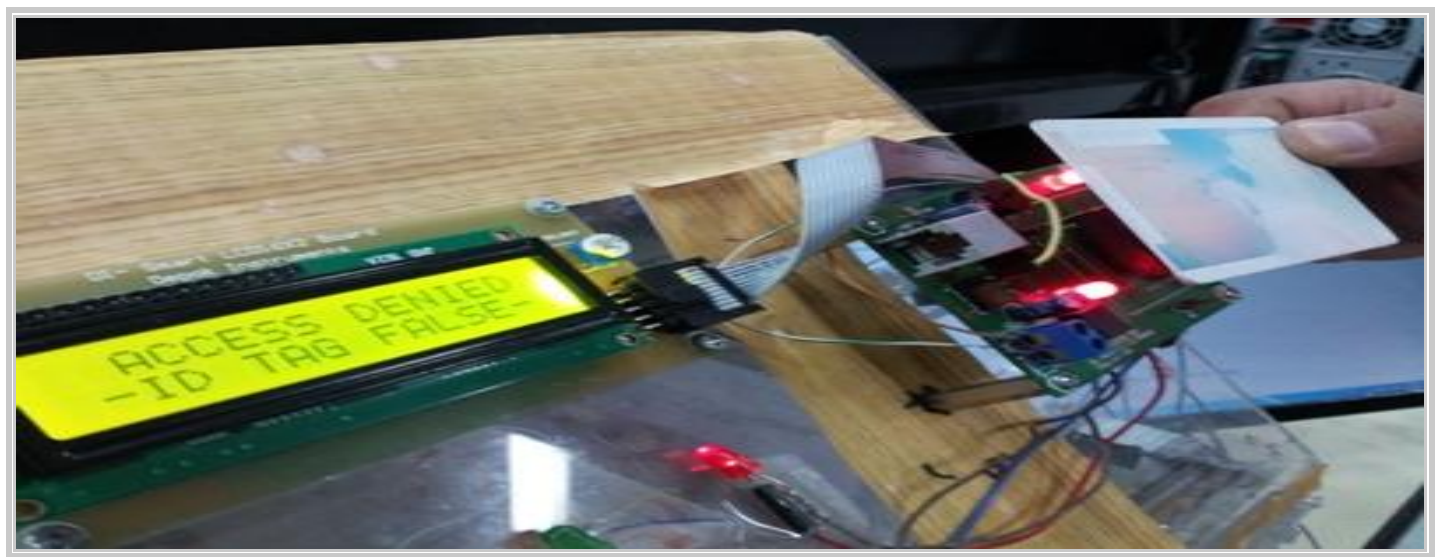

Gambar 15. ID Tag Salah

Gambar 15 merupakan hasil uji coba dengan memasukan ID tag yang salah. Tampil kalimat di LCD “ACCESS DENIED” dan "ID TAG FALSE". Selanjutnya tampil informasi di website secara otomatis seperti gambar 16 berikut. 


\section{STATUS N}

ACCESS DENIED

ID TAG FALSE

Gambar 16. Access Denied "ID TAG FALSE"

\section{Uji Coba Sensor Infrared Fotodioda}

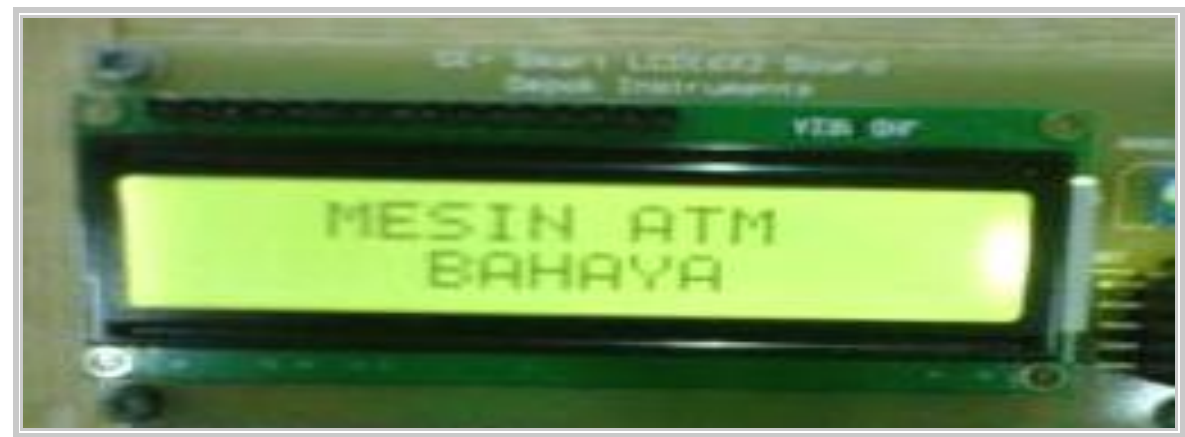

Gambar 17. Sensor Infrared Fotodioda terhalangi

Gambar 17 merupakan hasil uji coba ketika sensor1 dan sensor2 terhalang, maka tampil kalimat pada LCD "MESIN ATM BAHAYA". Tampilan di website seperti pada gambar 18 dibawah ini:

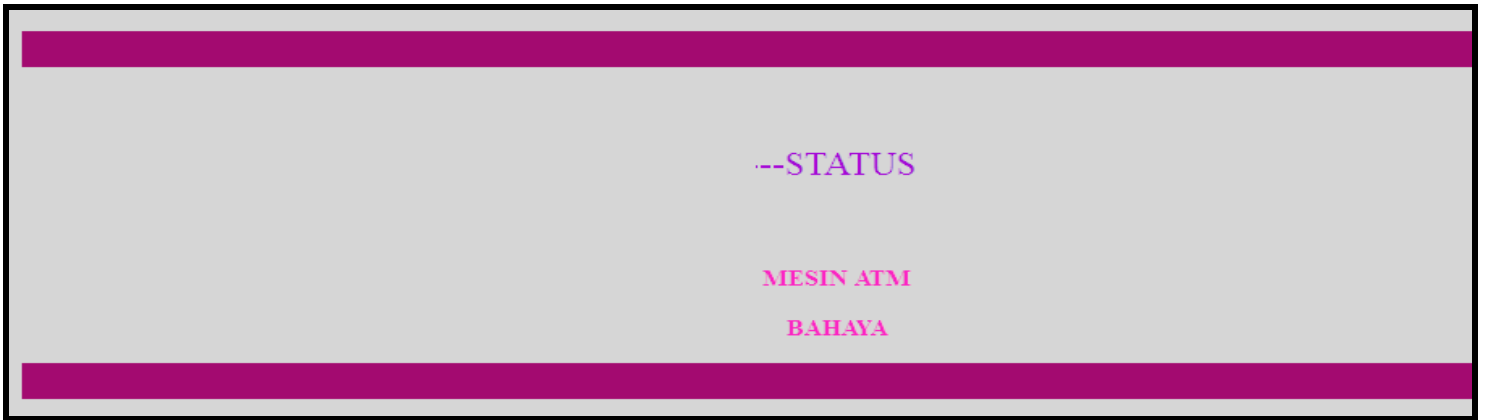

Gambar 18. Mesin ATM Bahaya

\section{KESIMPULAN}

Berdasarkan dari hasil perancangan dan pengujianyang sudah dilakukan, menunjukkan bahwa rancangan alat yang sudah dibuat dapat bekerja sesuai dengan yang sudah direncanakan, sehingga sistem keamanan menjadi lebih meningkat. Dengan demikian dapat disimpulkan adanya rancang bangun keamanan mesin ATM maka keamanan mesin ATM lebih meningkat dengan kelebihan rancangan penelitian diuraikan sebagai berikut:

1. Perancangan sistem keamanan mesin ATM menggunakan RFID berbasis mikrokontroler ATMega 8535 telah berhasil diimplementasikan dalam bentuk prototype yang berjalan secara otomatis mulai dari RFID, sensor, dan proses pengiriman data ke Website menggunakan port paralel DB 25. 
2. Mesin ATM dapat dibuka dan ditutup melalui jarak jauh dengan media button open dan close pada website secara online.

3. Jika mesin ATM dibongkar secara paksa maka buzzer berbunyi, selain itu di LCD dan Website tampil informasi mesin ATM bahaya.

\section{SARAN}

Penelitian selanjutnya diharapkan komponen yang menghubungkan antara alat dan website dapat menggunakan modul kontrol wirelesss supaya jarak lebih jauh dan untuk pengembangan lebih lanjut RFID reader dapat ditambahkan NFC (Near Field Communication).

\section{DAFTAR PUSTAKA}

[1] Ariessanti, H.D., Radiyanto dan Yuswanto, A.S.2015.Pengaman Brankas Menggunakan Voice dengan Media Bluetooth Berbasis Mikro-kontroller Atmega 328. Techno.COM, vol. 9, No. 1, pp. 27-32.

[2] Annisya,Lingga Hermanto,danRobby Candra.2017.Sistem Keamanan Buka Tutup Kunci Brankas Menggunakan Sidik Jari Berbasis Arduino Mega”.Universitas Gunadarma, Jurnal Informatika dan Komputer, vol 22 No. 1, April 2017.

[3] Figa Undala, Dedi Triyanto, Yulrio Brianorman.2015.Rototype Sistem Keamanan Pintu Menggunakan Radio Frequency Identification (Rfid) Dengan Kata Sandi Berbasis Mikrokontroler.Universitas Tanjung Pura.Jurnal Coding, Sistem Komputer Untan ,vol03, No. 1 (2015), hal 30-40.

[4] Agus Wibowo, Hendro Setiadi, dan Prihadi Beny Waluyo.2015.Sistem Pengamanan Brangkas Menggunakan Kombinasi Pin, Rfid, Dan Sms Berbasis Mikrokontroler Avr Atmega32.Universitas Kristen Duta Wacana. INFORMATIKA, vol. 11, No. 1, April 2015.

[5] Eni Yuliza, Toibah Umi Kalsum .2015.Alat Keamanan Pintu Brankas Berbasis Sensor Sidik Jari Dan Passoword Digital Dengan Menggunakan Mikrokontroler Atmega 16.Universitas Dahesan Bengkulu.Jurnal Media Infotama, vol. 11 No. 1, Februari 2015.

[6] Hani Dewi Ariessanti,Radiyanto,danAfridha Septian Yuswanto .2015.Pengaman Brankas Menggunakan Voice Dengan Media Bluetooth Berbasis Mikrokontrller Atmega 328”.STMIK Raharja,vol.9 No.1 - September 2015.ISSN :1978 -8282.

[7] Khairul Agus Rizal dan Naziruddin, dan Zamzami.2016.Sistem Pengaman Brankas Menggunakan Kode Password Dan Sidik Jari Berbasis Mikrokontroller.Politeknik Negeri Lokshumawe.Jurnal Litek, (ISSN: 1693-8097) vol 13 Nomor 1, Maret 2016: hal. 37-43.

[8] Mangasi Sirait dan Kasmir Tanjung.2015.Perancangan Sistem Keamanan Akses Buka Pintu Menggunakan Rfid (Radio Frequency Identification) dan Pengiriman Informasi KePonsel.Universitas Sumatera Utara.Singuda Ensikom, vol.13 NO.37/DESEMBER 2015.

[9] Muchommad Sobri Sungkar dan Tauchid Riyadi.2016.Perancangan Sistem Pengaman Brankas Berbasis PLC'.Politeknik Harapan Bersama.SENIT 2016, ISBN: 978-60274355-0-6.

[10] Mulyapriadi Wijaya dan Tjandra Susila.2016.Sistem Keamanan Brankas Secara Otomatis Berbasis Mikrokontroler Dengan Menggunakan Sms Serta Pin Dan RFID”.Universitas Tarumanegara.T E S L A, vol. 18 NO.2 OKTOBER 2016.

[11] Pinrolinvic Manembu, Mark D. Rembet, dan Angreine Kewo.2015.Sistem Pengaman Pintu Jamak dengan RFID Sensor berbasis WebSistem. Universitas Atmajaya.Jurnal Elektro, Vol 8, No 2 (2015).ISSN:1979-9780.

[12] Purhendi Bayu Basuki, Unang Sunarya, S.T., M.T.,dan Atik Novianti, S.ST., M.T.2017.Perancangan Sistem Keamanan Sepeda Di Tempat Umum Berbasis RFID”.Universitas Telkom.Jurnal Elektro Telekomunikasi Terapan, Juli 2017. 